\title{
Immunosuppressive cells identified in mouse models of SLE
}

Systemic lupus erythematosus (SLE) predominantly affects females. A group of immunosuppressive neutrophil-like cells has now been identified that seems to confer resistance to SLE, and might explain the gender bias in its incidence. These cells are found in higher numbers

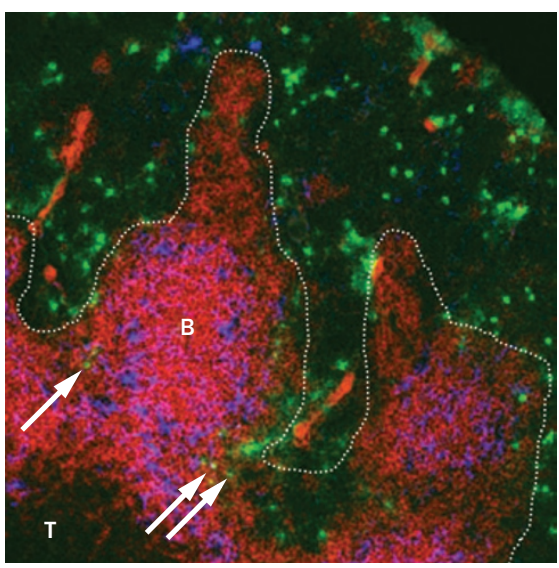

Confocal microscopy of a spleen from an SLE-prone male mouse stained with antibodies against Gr1 (green), B220 (red) and MOMA-1 (blue). Abbreviations: B, B-cell follicle;

T, T-cell zone. Permission obtained from Wiley @ Trigunaite et al. Arthritis Rheum. doi:10.1002/art.38048 in male mice than in females, are located adjacent to B-cell follicles in the spleen, are regulated by testosterone, and inhibit B-cell differentiation and antibody production ex vivo.

Previous research has primarily focused on the identification of femalespecific factors that increase the immune response; Trine Jørgensen and colleagues took the opposite approach. "The hope was to identify a protective mechanism (downstream of testosterone) that could be amplified in females with few adverse effects and prevent, delay or diminish disease progression," she explains. In an SLE-prone mouse strain-in which $100 \%$ of female mice and $30 \%$ of male mice develop an SLE-like phenotype by 1 year-more cells expressing the neutrophil markers Gr1 and CD11b $\left(\mathrm{Gr} 1^{\text {high }} \mathrm{CD} 11 \mathrm{~b}^{+}\right.$cells) were found in males than in females. Castration decreased the number of $\mathrm{Gr} 1^{\text {high }} \mathrm{CD} 11 \mathrm{~b}^{+}$ cells, an effect that could be reversed by treating castrated males with synthetic testosterone that cannot be converted into oestradiol.

Notably, antibody-mediated depletion of these cells in adult male mice increased the production of antinuclear antibodies and the deposition of IgG immune complexes in the kidney glomeruli compared with untreated mice matched for age and sex. The same antibody treatment had no effect in female mice. Gr $1^{\text {high }} \mathrm{CD} 11 \mathrm{~b}^{+}$cells might, therefore, have an important role in preventing autoimmunity in individuals predisposed to SLE.

Jørgensen now hopes to "identify the mechanism of suppression, and also to induce the differentiation of these immunosuppressive cells in young female mice." She also plans to look for similar cell populations in people predisposed to SLE.

Megan Cully

Original article Trigunaite, A. et al. Gr1 ${ }^{\text {high }} \mathrm{CD} 11 \mathrm{~b}^{+}$cells suppress $B$ cell differentiation and lupus-like disease in lupusprone male mice. Arthritis Rheum. doi:10.1002/art.38048 